\title{
Pengaruh Pendapatan dan Konsumsi Rumah Tangga terhadap Kesejahteraan Keluarga Petani Penggarap Sawit di Kecamatan Kumpeh Kabupaten Muaro Jambi
}

\author{
M. Alhudhori ${ }^{*}$, Muhammad Amali ${ }^{2}$ \\ ${ }^{1,2}$ Fakultas Ekonomi Universitas Batanghari Jambi \\ *Correspondence email: alhudhori811@gmail.com
}

\begin{abstract}
The consumption activities of each family have different spending types. The difference in consumption patterns in each family is used as a burden or dependents in fulfilling the needs of all family members, so that it is used as a measure of the family welfare evenly and intact. Rural populations have higher levels of consumption compared to urban populations. Welfare in the essence of fulfillment of all needs by doing consumption activities, which are filled with income that has to achieve satisfaction. The purpose of this research is to know the influence of income and household consumption to the welfare of smallholder farmer family in Kumpeh sub-district of Muaro Jambi. The results of this study revealed that the income and household consumption jointly influence positive and significant to the welfare of the farmer family of oil palm farmers in Kumpeh sub-district Muaro Jambi
\end{abstract}

Keywords: income, household consumption, family welfare farmer

\section{Pendahuluan}

Kesejahteraan Keluarga adalah suatu kondisi dinamis keluarga dengan terpenuhinya semua kebutuhan fisik materil, mental spiritual dan sosial, yang memungkinkan keluarga dapat hidup wajar sesuai dengan lingkungannya serta memungkinkn anak-anak tumbuh kembang dan memperoleh perlindungan yang diperlukan untuk membentuk sikap mental dan kepribadian yang mantap dan matang sebagai sumber daya manusia yang berkualitas (Bapermaskb: 2010/2011). Sedangkan dari pandangan yang berbeda dinyatakan bahwa keluarga sejahtera adalah keluarga yang dibentuk berdasarkan atas perkawinan yang sah, mampu memenuhi kebutuhan hidup spiritual dan materiil yang layak, bertaqwa kepada Tuhan Yang Maha Esa, memiliki hubungan yang serasi, selaras dan seimbang antar anggota dan antar keluarga dengan masyarakat dan lingkungan (UU No. 52/2009).

Ketergantungan terhadap pendapatan dan konsumsi hingga dapat mencapai kesejahteraan terjadi pada semua jenis pekerjaan termasuk petani penggarap sawit sebagai buruh penggarap sawit. Komoditas sawit di Temanggung merupakan salah satu produk unggulan.Produksi sawit Temanggung termasuk terbesar di Jawa Tengah yaitu 40\% produksi sawit Jawa Tengah berasal dari Temanggung. Kecamatan Candiroto dinyatakan sebagai Kecamatan penghasil sawit terbesar di Kabupaten Temanggung (Statistik Daerah Kab. Temanggung, 2013). Tanaman sawit ditanam pada 9 Desa dari 14 Desa yaitu pada wilayah Desa Mento-Desa Sidoharjo, diketahui sebanyak 56\% keluarga ((3610:6417) x 100\%) di wilayah Perkebunan sawit mengandalkan sumber daya alam untuk memenuhi kebutuhan dengan bekerja sebagai petani, buruh tani maupun buruh harian lepas. Buruh harian lepas merupakan buruh yang benar-benar memiliki pendapatan hanya dari pekerjaannya sebagai buruh dan tidak memiliki lahan perkebunan.Kebutuhan itu bisa bermacam-macam, berkembang dan berubah, bahkan seringkali tidak disadari oleh pelakunya.Kerja merupakan sesuatu yang dibutuhkan oleh manusia. Seseorang bekerja karena ada sesuatu yang hendak dicapainya, dan orang berharap bahwa aktivitas kerja yang dilakukannya akan membawanya kepada suatu keadaan yang lebih memuaskan daripada keadaan sebelumnya (Anoraga, 2005). Pekerjaan sebagai buruh penggarap sawit dijadikan sebagai satu-satunya tujuan mendapatkan penghasilan untuk memenuhi kebutuhan yang berubah-ubah dan semakin meningkat sesuai dengan perkembangan zaman.Mereka tidak memiliki pilihan selain tetap bertahan walaupun upah yang diberikan masih rendah.

Tabel 1

Upah Buruh

\begin{tabular}{clrrr}
\hline \multirow{2}{*}{ No } & \multicolumn{1}{c}{ Buruh } & Penggarapan & \multicolumn{2}{c}{ Upah Harian } \\
\cline { 4 - 5 } & & - & \multicolumn{1}{c}{ Laki-laki } & Perempuan \\
\hline 1 & Petani Pala Wija & 4 Bulan & 40.000 & 55.000 \\
2 & Petani Tembakau & - & 65.000 & 30.000 \\
3 & Petani Sawit & & & 55.000 \\
\hline
\end{tabular}

Sumber: Kelompok Pertanian Desa, 2018 
Kegiatan konsumsi setiap keluarga memiliki jenis pengeluaran yang berbeda. Perbedaan pola konsumsi pada setiap keluarga dijadikan sebagai beban atau tanggungan dalam memenuhi kebutuhan semua anggota keluarga, sehingga dijadikan sebagai ukuran tercapainya kesejahteraan keluarga secara merata dan utuh (Pangaribowo, 2014). Pola konsumsi dapat dikenali berdasarkan alokasi penggunaannya. Penduduk pedesaan mempunyai tingkat konsumsi yang lebih tinggi dibandingkan dengan penduduk perkotaan. Sesungguhnya yang dilakukan penduduk pedesaan bukanlah tindakan pemborosan tetapi mereka melakukan konsumsi untuk mempertahankan tingkat hidup substensinya untuk hidup yang lebih baik. Berdasarkan pengaruh konsumsi terhadap kesejahteraan keluarga dapat dilihat dari pola konsumsi keluarga. Faktor-faktor yang menentukan pola konsumsi keluarga berasal dari dua golongan yaitu makanan dan non-makanan (Dumairy, 1996). Kesejahteraan pada hakekatnya terpenuhinya segala kebutuhan dengan melakukan kegiatan konsumsi, yang dipenuhi dengan pendapatan yang dimiliki hingga mencapai kepuasan. Tujuan penelitian ini adalah untuk mengetahui pengaruh pendapatan dan konsumsi rumah tangga terhadap kesejahteraan keluarga petani penggarap sawit di Kecamatan Kumpeh Kabupaten Muaro Jambi.

\section{Tinjauan Pustaka \\ Kesejahteraan Keluarga}

Keadaan sejahtera relatif berbeda pada setiap individu maupun keluarga dan ditentukan oleh falsafah hidup masing-masing.Kondisi sejahtera bersifat tidak tetap dan dapat berubah setiap saat baik dalam waktu cepat atau lambat. Untuk mencapai dan mempertahankan kesejahteraan manusia harus berusaha secara terus menerus dalam batas waktu yang tidak dapat ditentukan, sesuai dengan tuntutan hidup yang selalu berkembang dan tidak ada batasan waktunya (Kuswardinah, 2007)

\section{Pendapatan}

Pendapatan merupakan suatu unsur penting dalam perekonomian yang berperan meningkatkan derajat hidup orang banyak melalui kegiatan produksi barang dan jasa.Besarnya pendapatan seseorang bergantung pada jenis pekerjaannya. Menurut Pass (1994), pendapatan adalah uang yang diterima oleh seseorang dan perusahaan dalam bentuk gaji, upah, sewa, bunga, laba dan lain sebagainya.Bersama-sama dengan tunjangan pengangguran, uang pensiun, dan lain sebagainya.Dalam analisis mikro ekonomi, istilah pendapatan khususnya dipakai berkenaan dengan aliran penghasilan dalam suatu periode waktu yang berasal dari penyediaan faktor-faktor produksi sumber daya alam, tenaga kerja dan modal yang masing-masing dalam bentuk sewa, upah dan bunga/laba secara berurutan.

\section{Konsumsi Rumah Tangga}

Dalam ilmu ekonomi, pengertian konsumsi lebih luas dari pada konsumsi yang terjadi dalam sehari-hari yang hanya dianggap berupa makanan dan minuman saja. Menurut Soeharno (2007) Konsumsi adalah kegiatan memanfaatkan barang-barang atau jasa dalam memenuhi kebutuhan hidup.

\section{Teori Perilaku Konsumen}

Schiffman dan Kanuk (1994), dalam bukunya yang berjudul ConsumerBehaviour, menyatakan bahwa perilaku konsumen adalah semua tindakan yangdilakukan seseorang untuk mencari, membeli, menggunakan, mengevaluasi dan menghabiskan produk. Dalam kegiatan mencari tentu saja tidak hanya sebatas pada barang dan jasa yang dibutuhkan melainkan juga terkait pada barang dan jasa yang diinginkan yang meliputi: kualitas, harga, ukuran, cara mendapatkannya, cara penggunaannya dan sebagainya (Nitisusastro, 2013).

\section{Perilaku Konsumen dalam Pemasaran}

Perilaku konsumen merupakan bagian dari manajemen pemasaran yang berhubungan dengan manusia sebagai pasar sasaran.Pelanggan merupakan komponen lingkungan yang mampu mempengaruhi pencapaian tujuan pemasaran.Prinsip pemasaran menyatakan bahwa pencapaian tujuan organisasi tergantung pada seberapa mampu organisasi tersebut memahami kebutuhan dan keinginan pelanggan dan memenuhinya secara lebih efisien dan efektif dibandingkan pesaing (Simamora, 2004).

\section{Metode}

Penelitian ini mengkaji tentang pengaruh pendapatan dan konsumsi rumah tangga terhadap kesejahteraan keluarga petani penggarap sawit di Kecamatan Kumpeh Kabupaten Muaro Jambi.Pendekatan yang digunakan dalam penelitian ini adalah kuantitatif yang bertujuan untuk menguji teori.Sebelum melakukan pengujian hipotesis-hipotesis dalam penelitian ini, terlebih dahulu diperlukan data-data yang relevan.Tujuan menggunakan pendekatan kuantitatif adalah untuk menguji hipotesis-hipotesis yang diajukan dalam penelitian berupa angka-angka dan analisis menggunakan statistik. Berdasarkan tingkat kealamiahan tempat penelitian, metode yang digunakan adalah metode 
survey yang digunakan untuk mendapatkan data dari tempat tertentu yang alamiah (bukan buatan), tetapi penelitian melakukan perlakuan dalam pengumpulan data, misalnya dengan mengedarkan kuesioner, test, wawancara terstruktur dan sebagainya (Sugiyono, 2012). Populasi adalah wilayah generalisasi yang terdiri atas: obyek/subyek yang mempunyai kualitas dan karakteristik tertentu yang ditetapkan oleh peneliti untuk dipelajari dan kemudian ditarik kesimpulan (Sugiyono, 2012). Objek dalam penelitian ini adalah seluruh keluarga petani penggarap sawit di Kecamatan Kumpeh Kabupaten Muaro Jambi. Jumlah populasi diambil dari 17.

Berdasarkan data diatas populasi dalam penelitian ini buruh harian lepas yang berjumlah 250 keluarga yang berasal dari 220 kepala keluarga laki-laki dan 30 kepala keluarga perempuan. Variabel penelitian pada dasarnya adalah segala sesuatu yang berbentuk apa saja yang ditetapkan oleh peneliti untuk dipelajari sehingga diperoleh informasi tentang hal tersebut, kemudian ditarik kesimpulannya (Sugiyono, 2012.

\section{Teknik Pengumpulan Data}

Kuesioner yang digunakan dalam penelitian ini adalah kuesioner tertutup. Kuesioner tertutup digunakan untuk mengumpulkan data berkaitan dengan variabel yang dalam pertanyaannya sudah disediakan alternatif pilihan jawaban pada masing-masing pertanyaan yang disediakan empat pilihan jawaban, untuk variabel pendapatan dan konsumsi rumah tangga yaitu dengan kategori: (1) Sangat cukup dengan skor 4; (2) cukup dengan skor 3; (3) kurang cukup dengan skor 2; dan (4) tidak cukup dengan skor 1. Sedangkan untuk variabel kesejahteraan keluarga yaitu dengan kategori: (1) Sangat terpenuhi dengan skor 4; (2) terpenuhi dengan skor 3; (3) kurang terpenuhi dengan skor 2; dan (4) tidak terpenuhi dengan skor 1 . Teknik pengumpulan data dalam dokumentasi digunakan untuk mengetahui data berkaitan dengan pendapatan dan konsumsi rumah tangga petani penggarap sawit Kecamatan Kumpeh Kabupaten Muaro Jambi.

\section{Teknik Analisis Data}

\section{Analisis Regresi Linear Berganda}

Analisis regresi ganda digunakan oleh peneliti, bila peneliti bermaksud meramalkan bagaimana keadaan (naik turunnya) variabel dependen (kriterium), bila dua atau lebih variabel independent sebagai faktor prediktor dimanipulasi (dinaik turunkan nilainya) (Sugiyono, 2006:250). Analisis regeresi ini digunakan untuk mengetahui pengaruh antara variabel independen dan variabel dependen, yaitu: pendapatan, konsumsi rumah tangga dan kesejahteraan keluarga. Berikut rumus persamaan regresi linier berganda dengan dua prediktor:

$\mathrm{Y}=\mathrm{a}_{0}+\mathrm{b}_{1} \mathrm{X}_{1}+\mathrm{b}_{2} \mathrm{X}_{2}+\mathrm{e}$

Keterangan: $\mathrm{Y}=$ variabel terikat (kesejahteraan keluarga); $a_{0}=$ konstanta; $\mathrm{X}_{1}=$ variabel bebas (pendapatan); $\mathrm{X} 2=$ variabel bebas (konsumsi untuk rumah tangga); $b_{1}=$ koefisien variabel $\mathrm{X}_{1} ; \mathrm{b}_{2}=$ koefisien variabel $\mathrm{X}_{2} ; \mathrm{e}=$ kesalahan pengganggu

\section{Hasil}

\section{Analisis Deskriptif Variabel Kesejahteraan Keluarga}

Varibel kesejahteraan keluarga dalam penelitian ini meliputi tiga indikator, yaitu pemenuhan pada kebutuhan pokok, kebutuhan sosial dan kebutuhan pengembangan. Pada variabel kesejahteraan keluarga terdapat 17 pernyataaan yang diberikan kepada 71 responden keluarga petani penggarap kelapa sawit di Kecamatan Kumpeh Kabupaten Muaro Jambi. Hasil analisis deskriptif berkaitan dengan kesejahteraan keluarga terangkum dalam tabel berikut:

Tabel 2

Hasil Analisis Derkriptif Variabel Kesejahteraan Keluarga

\begin{tabular}{lcrrr}
\hline \multicolumn{1}{c}{ No } & Interval & Kategori & Frekuensi & \multicolumn{1}{c}{ Skor } \\
\hline 1 & $3923 \geq$ Skor $\leq 4828$ & Sangat Tinggi & 0 & $0.00 \%$ \\
2 & $3017 \geq$ Skor $\leq 3922$ & Tinggi & 25 & $35.21 \%$ \\
3 & $2111 \geq$ Skor $\leq 3016$ & Rendah & 45 & $63.38 \%$ \\
4 & $1205 \geq$ Skor $\leq 2110$ & Sangat Rendah & 1 & $1.41 \%$ \\
Jumlah & 71 & $100 \%$ & 2914 & Rendah \\
\hline
\end{tabular}

Sumber: data diolah

Tabel 2 diketahui bahwa dari hasil analisis deskriptif variabel kesejahteraan keluarga diperoleh total skor sebesar 2914 dengan persentase sebesar $60.4 \%$, yang berada pada interval $2111 \geq$ Skor $\leq 3016$ dan termasuk dalam kategori rendah. Dalam penelitian tersebut diketahui bahwa sebanyak 0 keluarga berada pada interval $3923 \geq$ Skor $\leq$ 4828 yang termasuk dalam kategori sangat tinggi, 25 keluarga berada pada interval $3017 \geq$ Skor $\leq 3922$ yang termasuk dalam kategori Tinggi, 45 keluarga berada pada interval $2111 \geq$ Skor $\leq 3016$ yang termasuk dalam kategori 
M. Alhudhori dan Muhammad Amali, Pengaruh Pendapatan dan Konsumsi Rumah Tangga Terhadap Kesejahteraan Keluarga Petani Penggarap Sawit di Kecamatan Kumpeh Kabupaten Muaro Jambi

rendah dan sebanyak 1 keluarga berada pada interval $1205 \geq$ Skor $\leq 2110$ yang termasuk dalam kategori sangat rendah.

Analisis Regresi Linier Berganda

Tabel 3

Hasil Analisis Regresi Berganda

\begin{tabular}{|c|c|c|c|c|c|}
\hline \multirow{2}{*}{ Model } & \multicolumn{2}{|c|}{ Unstandardized Coefficients } & Standardize Coefficients & \multirow[b]{2}{*}{$\mathrm{t}$} & \multirow{2}{*}{ Sig. } \\
\hline & $\mathrm{B}$ & Std. Error & Beta & & \\
\hline (Constant) & 16.032 & 5.218 & & 3.072 & .003 \\
\hline Pendapatan & .444 & .184 & .255 & 2.411 & .019 \\
\hline Konsumsi Rumah Tangga & .283 & .074 & .405 & 3.825 & .000 \\
\hline
\end{tabular}

Sumber: Data diolah

Berdasarkan Tabel 3 diperoleh persamaan regresi berganda sebagai berikut:

$\mathrm{Y}=16.032+0.444 \mathrm{X}_{1}+0.283 \mathrm{X}_{2}$, persamaan regresi tersebut mempunyai makna sebagai berikut:

a. Konstanta $=16.032$, konstanta sebesar 16.032 dapat diartikan jika variabel bebas (pendapatan dan konsumsi rumah tangga) dalam model sama $=0$ (nol), maka secara rata-rata variabel di luar model memberikan nilai pada kesejahteraan keluarga sebesar 16.032.

b. Koefisien $X_{1}=0.444$, koefisien regresi pendapatan pada tabel diatas sebesar 0.444 serta bernilai positif artinya apabila pendapatan mengalami kenaikan sebesar 1 satuan karena nilai koefisien regresinya positif, sedangkan variabel konsumsi rumah tangga nilainya tetap, maka variabel kesejahteraan keluarga akan mengalami kenaikan sebesar 0.444 point, begitu juga sebaliknya.

c. Koefisisen $\mathrm{X}_{2}=0.283$, koefisien regresi konsumsi rumah tangga pada tabel diatas sebesar 0.283 serta bernilai positif artinya apabila konsumsi rumah tangga mengalami kenaikan sebesar 1 satuan karena nilai koefisien regresi positif, sedangkan pendapatan nilainya tetap, maka variabel kesejahteraan keluarga akan mengalami kenaikan sebesar 0.283 point, begitu juga sebaliknya.

\section{Pengujian Hipotesisi Secara Simultan (Uji F)}

Tabel 4

Hasil Pengujian Hipotesis Secara Bersama-Sama (Uji F)

\begin{tabular}{|c|c|c|c|c|c|c|}
\hline & Model & Sum of Squares & Df & Mean Square & $\mathrm{F}$ & Sig. \\
\hline \multirow[t]{3}{*}{1} & Regression & 435.645 & 2 & 217.822 & 12.668 & .000 \\
\hline & Residual & 1169.228 & 68 & 17.195 & & \\
\hline & Total & 1604.873 & 70 & & & \\
\hline
\end{tabular}

Sumber: Data diolah

Uji Koefisien Determinasi Secara Simultan $\left(R^{2}\right)$

Tabel 5

Uji Koefisien Determinasi Secara Simultan $\left(\mathbf{R}^{2}\right)$

\begin{tabular}{|c|c|c|c|c|}
\hline Model & $\mathbf{R}$ & R Square & Adjusted R Square & Std. Error of the Estimate \\
\hline 1 & $.521^{\mathrm{a}}$ & .271 & .250 & 4.14663 \\
\hline
\end{tabular}

Sumber: Data diolah .

\section{Pengaruh Pendapatan Terhadap Kesejahteraan Keluarga Petani Penggarap Kelapa sawit di Kecamatan Kumpeh Kabupaten Muaro Jambi}

Berdasarkan hasil penelitian dengan 71 responden keluarga sebagai sampel dari petani penggarap kelapa sawit di Kecamatan Kumpeh Kabupaten Muaro Jambi diperoleh keterangan bahwa variabel pendapatan berpengaruh positif dan signifikan terhadap kesejahteraan keluarga. Hal ini dapat dilihat dari uji parsialnya yang menunjukkan kontribusi pengaruh pendapatan terhadap kesejahteraan keluarga sebesar $7.89 \%$ dan dengan deskriptif variabel menunjukkan rata-rata pendapatan keluarga petani penggarap Sawit sebesar $60.77 \%$ dan masuk dalam kategori rendah. Hal ini berarti semakin rendah pendapatan yang dimiliki keluarga maka berdampak pada semakin rendah pula kesejahteraan keluarga. Hal tersebut terjadi karena pendapatan yang dimiliki akan berdampak dalam pemenuhan kebutuhan setiap keluarga sehingga ketika pendapatan tidak mencukupi untuk memenuhi kebutuhan akan mengurangi tingkat kesejahteraan keluarga. Pada pengukuran variabel deskriptif pendapatan didapatkan dari tiga indikator antaralain; 
penerimaan penghasilan, ketepatan pembayaran dan kesesuaian pekerjaan. Indikator tersebut digunakan atas dasar keterkaitan antara pendapatan dengan kesejahteraan keluarga.

\section{Pengaruh Konsumsi Rumah Tangga Terhadap Kesejahteraan Keluarga Petani Penggarap Kelapa sawit di Kecamatan Kumpeh Kabupaten Muaro Jambi}

BPS dan Dumairy (1996) yang membedakan konsumsi menjadi dua kelompok yaitu konsumsi makanan dan konsumsi bukan makanan. Konsumsi makanan terdiri dari barang yang tidak tahan lama, sedangkan konsumsi bukan makanan adalah konsumsi yang berguna untuk jangka waktu panjang dan dalam pemenuhannya bersifat insidental. Schiffman dan Kanuk (1994), dalam bukunya yang berjudul Consumer Behaviour, menyatakan bahwa perilaku konsumen adalah semua tindakan yang dilakukan seseorang untuk mencari, membeli, menggunakan, mengevaluasi dan menghabiskan produk. Dalam kegiatan mencari tentu saja tidak hanya sebatas pada barang dan jasa yang dibutuhkan melainkan juga terkait pada barang dan jasa yang diinginkan yang meliputi akan kualitas, harga, ukuran, cara mendapatkannya, cara penggunaannya dan sebagainya (Nitisusastro, 2013). Berdasarkan hasil penelitian dari 71 keluarga sebagai sampel dari petani penggarap kelapa sawit di Kecamatan Kumpeh Kabupaten Muaro Jambi diperoleh hasil bahwa konsumsi rumah tangga berpengaruh secara positif dan signifikan terhadap kesejahteraan keluarga. Hal ini dapat diketahui dengan uji parsialnya yang menunjukkan kontribusi pengaruh konsumsi rumah tangga terhadap kesejahteraan keluarga sebesar $17.72 \%$ dengan deskripsi variabel menunjukkan skor total sebanyak 3568 dengan persentase sebesar $62.8 \%$ dan termasuk dalam ketegori tinggi. Penelitian ini variabel konsumsi rumah tangga memberi kontribusi pengaruh yang lebih besar terhadap kesejahteraan dibandingkan dengan variabel pendapatan. Berdasarkan uji parsial variabel konsumsi rumah tangga diperoleh hasil signifikansi sebesar $0.000<0.05$ maka hipotesis yang berbunyi bahwa terdapat pengaruh konsumsi rumah tangga terhadap kesejahteraan keluarga petani penggarap kelapa sawit di Kecamatan Kumpeh Kabupaten Muaro Jambi (Ha) diterima. Hal ini ditunjukkan dari koefisien regresi sebesar 0.283 , nilai probabilitas $0.000<0.05$ dan koefisien determinan $\left(\mathrm{r}^{2}\right)$ Hasil penelitian 0.421 atau dapat dikatakan pengaruh konsumsi rumah tangga terhadap kesejahteraan keluarga sebesar $17.72 \%$ dan $82.28 \%$ ditentukan oleh variabel lain. Penelitian ini sesuai dengan penelitian yang dilakukan oleh Hendrik (2011) juga menunjukkan bahwa pendapatan berpengaruh secara signifikan dan positif terhadap kesejahteraan keluarga, begitu juga menurut Wagle et al, (2006) bahwa secara langsung konsumsi yang berasal dari pendapatan akan mempengaruhi kesejahteraan. Dengan demikian penelitian ini dapat diterima karena sesuai dengan teori yang ada.

\section{Pengaruh Pendapatan dan Konsumsi Rumah Tangga Terhadap Kesejahteraan Keluarga Petani Penggarap Kelapa sawit di Kecamatan Kumpeh Kabupaten Muaro Jambi}

Penelitian ini sesuai dengan penelitian Wegle et al (2006) dan Hendrik (2011) yang menyatakan bahwa variabel pendapatan dan konsumsi rumah tangga bersama-sama berpengaruh terhadap kesejahteraan keluarga. Perbedaan pada penelitian yang dilakukan oleh Wegle et al (2006) bahwa konsumsi rumah tangga yang akan menjadi pertimbangan adalah dengan adanya barang atau jasa jenis baru. Sedangkan perbedaan yang oleh penelitian yang dilakukan oleh hendrik (2011) bahwa yang menjadi ukuran konsumsi rumah tangga adalah terletak pada tingkat pendidikan, sedangkan pendapatan diukur dari cara yang digunakan dalam melakukan pekerjaannya.

\section{Simpulan}

Hasil penelitian mengungkapkan sebagai berikut:

1. Pendapatan berpengaruh positif dan signifikan terhadap kesejahteraan keluarga petani penggarap kelapa sawit di Kecamatan Kumpeh Kabupaten Muaro Jambi. Jika variabel pendapatan naik sebesar satu persen maka kesejahteraan keluarga akan meningkat sebesar $7.89 \%$.

2. Konsumsi rumah tangga berpengaruh positif dan signifikan terhadap kesejahteraan keluarga petani penggarap kelapa sawit di Kecamatan Kumpeh Kabupaten Muaro Jambi. Jika variabel konsumsi rumah tangga naik sebesar satu persen maka kesejahteraan keluarga akan meningkat sebesar $17.72 \%$.

3. Pendapatan dan konsumsi rumah tangga secara bersama-sama berpengaruh positif dan signifikan terhadap kesejahteraan keluarga petani penggarap kelapa sawit di Kecamatan Kumpeh Kabupaten Muaro Jambi sebesar $27.1 \%$ dan sisanya $72.9 \%$ dipengaruhi oleh variabel lain yang tidak masuk dalam penelitian ini.

\section{Daftar Pustaka}

Anoraga, Pandji.2005.Psikologi Kerja.Jakarta:PT Rineka Cipta

Anwar, Rustini Chairul.1981. Pendidikan Keterampilan, Pendidikan Kesejahteraan Keluarga, Departemen Pendidikan dan Kebudayaan. Jakarta: CV. Jasanku

Dumairy.1996.Perekonomian Indonesia. Jakarta: Erlangga

Engel, James F. et, al.1994.Perilaku Konsumen Edisi Keenam Jilid 1. Alih Bahasa Budiyanto.Jakarta Binarupa Aksara 
Falih, Ahmad.2007. Pengaruh Besarnya Upah Buruh Tani Terhadap Perilaku Konsumsi Kerja dan Konsumsi (Studi Pada Usaha Tani Bawang Merah di Kabupaten Brebes).Tesis. Jakarta: Fakultas ekonomi UIN Syarif Hidayatullah

Ghozali, Imam. 2011. Aplikasi Analisis Multivariate Dengan Program IBM SPSS 19. Semarang: Universitas Diponegoro.

Habibi, Maksum dan Gunadi.2013.Pengantar Ekonomi dan Bisnis, Bidang Keahlian Bisnis dan Manajemen SMK Kelas X. Jakarta: Yudhistira

Hendrik.2011. Analisis Pendapatan dan Tingkat Kesejahteraan Masyarakat Nelayan Danau Pulau Besar dan Danau Bawah di Kecamatan Dayun Kabupaten Siak Provinsi Riau. Dalam Jurnal Perikanan dan Kelautan, volume 16 No. 1. Hal 21-32 Riau:Universitas Riau

Ishak, Ismahalil. 2012.Kajian Indikator Kesejahteraan Keluarga. Seminar Penggunaan Data-data Hasil Penyelidikan, Daripada Persepsi Ke Realiti: Malaysia: Lembaga Penduduk dan Pembangunan Keluarga Negara

Kuswardinah, Asih.2007.Ilmu Kesejahteraan Keluarga.Semarang:Universitas Negeri Semarang Prees

Kotler, Philip dan Kevin Lane Keller.2009.Manajemen Pemasaran Edisi Kedua Belas Jilid 1.Alih bahasa Benyamin Molan.Jakarta: PT Indeks

Nanga, Muana. 2001.Makro Ekonomi:teori, masalah dan kebijakan Edisi 1. Jakarta: PT Raja Grafindo persada

Ndakularak, Erwin. Seyiawina dkk. 2011. Faktor-faktor yang mempengaruhi kesejahteraan keluarga. Sumatera Utara: Universitas Sumatera Utara. 